Provided for non-commercial research and education use. Not for reproduction, distribution or commercial use.

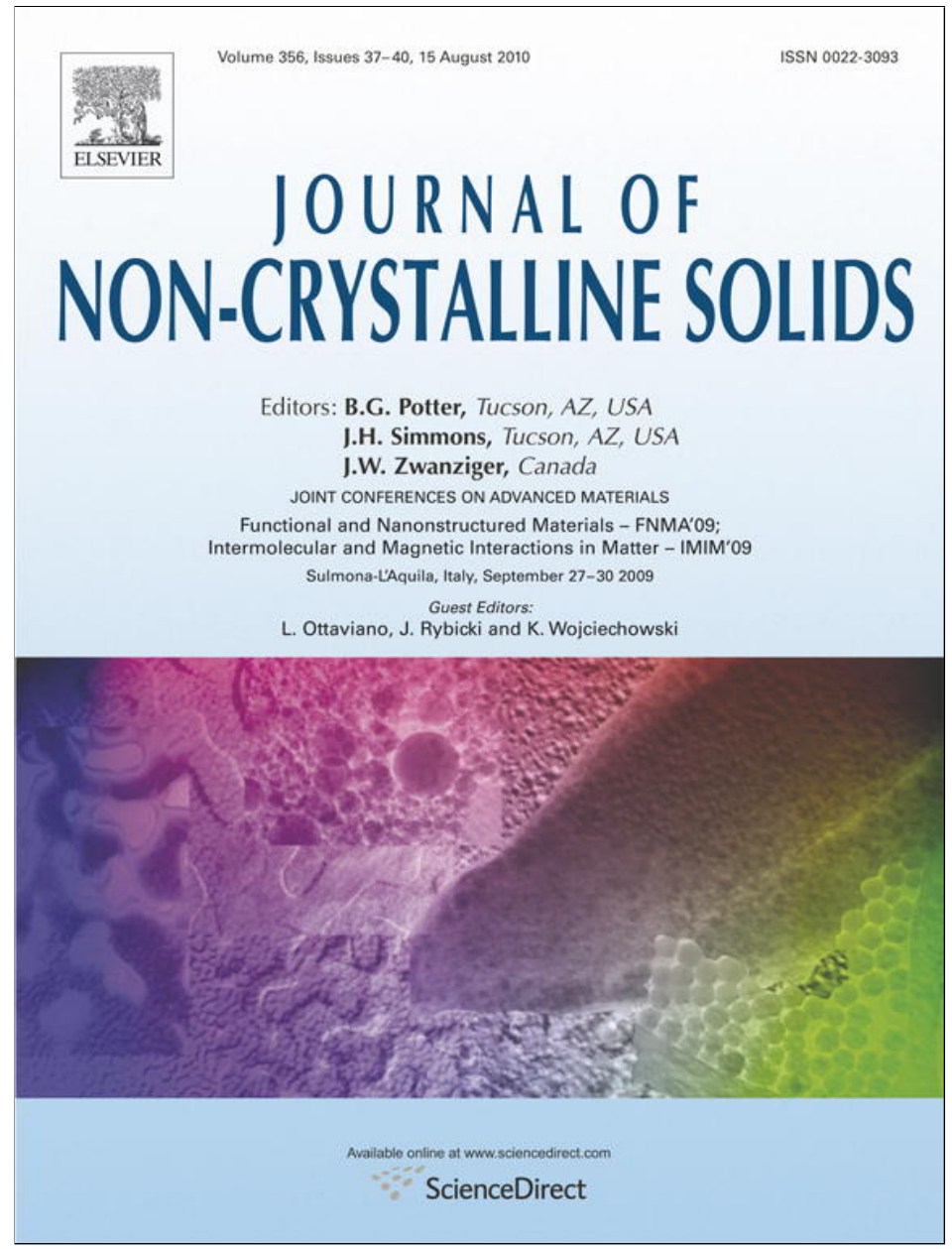

This article appeared in a journal published by Elsevier. The attached copy is furnished to the author for internal non-commercial research and education use, including for instruction at the authors institution and sharing with colleagues.

Other uses, including reproduction and distribution, or selling or licensing copies, or posting to personal, institutional or third party websites are prohibited.

In most cases authors are permitted to post their version of the article (e.g. in Word or Tex form) to their personal website or institutional repository. Authors requiring further information regarding Elsevier's archiving and manuscript policies are encouraged to visit:

http://www.elsevier.com/copyright 


\title{
Optimization of nanostructured titania photoanodes for dye-sensitized solar cells: Study and experimentation of $\mathrm{TiCl}_{4}$ treatment
}

\author{
Luigi Vesce a,b, Riccardo Riccitelli ${ }^{\mathrm{c}}$, Giuseppe Soscia ${ }^{\mathrm{a}, \mathrm{b}}$, Thomas M. Brown ${ }^{\mathrm{a}, \mathrm{b}}$, \\ Aldo Di Carlo ${ }^{\mathrm{a}, \mathrm{b}}$, Andrea Reale $\mathrm{a,b}, *$ \\ a CHOSE-Centre for Hybrid and Organic Solar Energy, Via G. Peroni 400/402, 00131 Rome, Italy \\ b Electronic Engineering Department, University of Rome "Tor Vergata", Via del Politecnico 1, 00133 Rome, Italy \\ c DYERS Srl, Via G. Peroni 400/402, 00131 Rome, Italy
}

\section{A R T I C L E I N F O}

\section{Article history:}

Received 22 May 2010

Available online 26 June 2010

\section{Keywords:}

Dye-sensitized solar cells (DSC);

Meso-porous $\mathrm{TiO}_{2}$ layers;

photon-trapping effect;

$\mathrm{TiCl}_{4}$ treatment

DSC electrodes;

DSC fabrication:

Highly efficient DSC

\begin{abstract}
A B S T R A C T
Titanium tetrachloride $\left(\mathrm{TiCl}_{4}\right)$ treatment processed by chemical bath deposition is usually adopted as preand post-treatment for nanocrystalline titanium dioxide $\left(\mathrm{TiO}_{2}\right)$ film deposition in the dye-sensitized solar cell (DSC) technology. Pre-treatment influences positively the bonding strength between the fluorinated tin oxide (FTO) substrate and the porous $\mathrm{TiO}_{2}$ layer, blocking the charge recombination at the interface between the conduction glass FTO and the $\mathrm{I}_{3}^{-}$ions present in the $\mathrm{I}^{-} / \mathrm{I}_{3}^{-}$red-ox couple. Additionally, $\mathrm{TiCl}_{4}$ posttreatment is a widely known method capable of improving the performance of dye-sensitized solar cells, in particular, the photocurrent collected from the device.

In this study, the influence and effect of $\mathrm{TiCl}_{4}$ pre- and post-treatment on the $\mathrm{TiO}_{2}$ layer is proposed and compared to the untreated film. The relative DSC devices are characterized in terms of short circuit current density, open circuit voltage, fill factor, conversion efficiency and IPCE.

The dark current characteristics of cells with a treated and untreated $\mathrm{TiO}_{2}$ layer are also shown in order to evaluate the effect of $\mathrm{TiCl}_{4}$ pre-treatment as a blocking layer.
\end{abstract}

() 2010 Elsevier B.V. All rights reserved.

\section{Introduction}

Since the introduction and development of the dye-sensitized solar cell (DSC) [1] several efforts have been made to optimize the materials involved in the photo-electrochemical process and to improve the light conversion efficiency of the device [2].

Among the different steps in the realization of efficient DSCs, the control of the quality, morphology and design of the mesoporous wide band-gap titanium dioxide $\left(\mathrm{TiO}_{2}\right)$ layer is of fundamental importance [3]. In recent designs a highly porous nanocrystalline $\mathrm{TiO}_{2}$ film (with a large effective surface area), deposited using the techniques of screen-printing or blade coating [4], has been typically optimized by depositing a second light-scattering layer [5]. The first porous layer is responsible for the increase in the amount of the dye adsorbed and makes a simple electrolyte diffusion. The scattering of light, due to the second layer, increases the path length of photons inside the cell and the probability to interact with a dye molecule [6]. The photon-trapping effect can be so induced by the use of a combination of a transparent nanocrystalline $\mathrm{TiO}_{2}$ film with a

\footnotetext{
* Corresponding author. Electronic Engineering Department, University of Rome "Tor Vergata", Via del Politecnico 1, 00133 Rome, Italy. Tel.: + 3906 72597372; fax: + 3906 72597939.

E-mail address: reale@ing.uniroma2.it (A. Reale).
}

microcrystalline light-scattering layer $[7,8]$, in conjunction with the anti-reflecting film (ARF) [9] and other techniques [10].

A widely known method to improve the DSC performance is treatment of fluorinated tin oxide (FTO) covered glass (pre-treatment) and $\mathrm{TiO}_{2}$ film (post-treatment) with an aqueous solution of titanium tetrachloride $\left(\mathrm{TiCl}_{4}\right)$ [11]. The pre- and post-treatment is the complete treatment.

The pre-treatment influences positively the bonding strength between the FTO substrate and the porous $\mathrm{TiO}_{2}$ layer and blocks the charge recombination between electrons emanating from the FTO and the $\mathrm{I}_{3}^{-}$ ions present in the $\mathrm{I}^{-} / \mathrm{I}_{3}^{-}$red-ox couple [12]. To reduce the charge recombination at the FTO/electrolyte interface, Ito and his coworkers have demonstrated that a high open circuit photo-voltage is required to prevent the recapture of photo-injected electrons by $\mathrm{I}_{3}^{-}$[13].

The $\mathrm{TiCl}_{4}$ post-treatment results in an improvement of the photocurrent but its real effect is not quite clear. In particular, the hypothesis that can explain the improvement of the injection of an electron is still controversial. O'Regan et al. [14] have shown that the main effects of this treatment are a downward shift in the $\mathrm{TiO}_{2}$ conduction band edge potential and a decrease in the electron/electrolyte recombination rate constant. Together, these changes increase the quantum efficiency of charge separation at the interface.

Moreover, morphological changes and shifts in the Raman spectra of cells with treated $\mathrm{TiO}_{2}$ layer have been also remarked [15]. A generation of new rutile layers on the rutile $\mathrm{TiO}_{2}$ surface has been reported, 
resulting in epitaxial growth of new layers on the electrode surface made entirely of rutile nanoparticles. As has been already shown [16], the $\mathrm{TiCl}_{4}$ treatment decreases the surface area of the films, as well as the average pore size and the porosity. All these data suggest that the titanium complexes present in the $\mathrm{TiCl}_{4}$ solution condense at the interpart of the film. This hypothesis is consistent with the pore-size reduction, the surface-area loss, and the density variation that are observed in the films after $\mathrm{TiCl}_{4}$ treatment.

In this study, pre- and post- $\mathrm{TiCl}_{4}$ treatment of a $\mathrm{TiO}_{2}$ layer was processed and the improvement in the photocurrent for a relative DSC device was evaluated and investigated, analyzing the effect also after two months from the fabrication of cells. In addition, the concentration and volume solution influence on the treatment was highlighted.

\section{Experimental section}

The DSCs were fabricated by the following procedure [4,17]. The substrates were $8 \Omega / \mathrm{sq}$ FTO-glass ( $2 \mathrm{~cm} \times 2 \mathrm{~cm}$, Pilkington) cleaned in an ultrasonic bath for $10 \mathrm{~min}$ in acetone and for $5 \mathrm{~min}$ in ethanol. $5 \mathrm{~mm} \times 5 \mathrm{~mm} \mathrm{\textrm {TiO } _ { 2 }}$ films (thickness $\sim 15 \mu \mathrm{m}$ ) deposited via blade coating using Dyesol DSL 18 NR-T TiO 2 paste, dried for 15 min at $50^{\circ} \mathrm{C}$, for $15 \mathrm{~min}$ at $70{ }^{\circ} \mathrm{C}$ and then sintered at $525^{\circ} \mathrm{C}$ for $30 \mathrm{~min}$. After sintering the transparent substrates were soaked in a $0.5 \mathrm{mM}$ N719 (B2, Dyesol) dye solution in ethanol for $15 \mathrm{~h}$, and then rinsed in ethanol. The counter-electrodes were prepared by screen-printing Dyesol PT1 Platinum paste onto the FTO-coated substrates, dried for $10 \mathrm{~min}$ at $80^{\circ} \mathrm{C}$ and then annealed at $420^{\circ} \mathrm{C}$ for $15 \mathrm{~min}$. The cells were completed by sealing together the two electrodes via a $60 \mu \mathrm{m}$ thick Surlyn (Solaronix) gasket. One batch of devices with a Dyesol High Stability Electrolyte (HSE) mediator inserted into the cell via vacuum backfilling was fabricated.

The $\mathrm{TiCl}_{4}$ solution was diluted in aqueous solution with a final concentration of $40 \mathrm{mM}$. The "pre-treated" photo-electrodes had the $\mathrm{TiCl}_{4}$ treatment after the cleaning step of the FTO covered glass. The "post-treated" photo-electrodes had the $\mathrm{TiCl}_{4}$ treatment after the $\mathrm{TiO}_{2}$ film sintering step. Both treatments were processed by dipping the samples into the $\mathrm{TiCl}_{4}$ solution at $70{ }^{\circ} \mathrm{C}$ for $30 \mathrm{~min}$, then rinsing in deionized water and ethanol and drying at room temperature in a vertical position. The aqueous $\mathrm{TiCl}_{4}$ solution for the pre-treatment was not reused for the post-treatment in order to achieve the best result. Following the post-treatment, the $\mathrm{TiO}_{2}$ film was annealed at $500{ }^{\circ} \mathrm{C}$ for $30 \mathrm{~min}$.

The experiment was conducted by testing the devices in a solar simulator (Solar constant $1200 \mathrm{KHS}$ ) at AM $1.5,1000 \mathrm{~W} / \mathrm{m}^{2}$ calibrated with a Skye SKS 1110 sensor and the cells performance was evaluated by the incident photon-to-current conversion efficiency (IPCE) set-up.

\section{Results}

Fig. 1 compares the scanning electron microscopy (SEM) images of a $\mathrm{TiO}_{2}$ film untreated and a film treated with the $\mathrm{TiCl}_{4}$ solution. Fig. 1

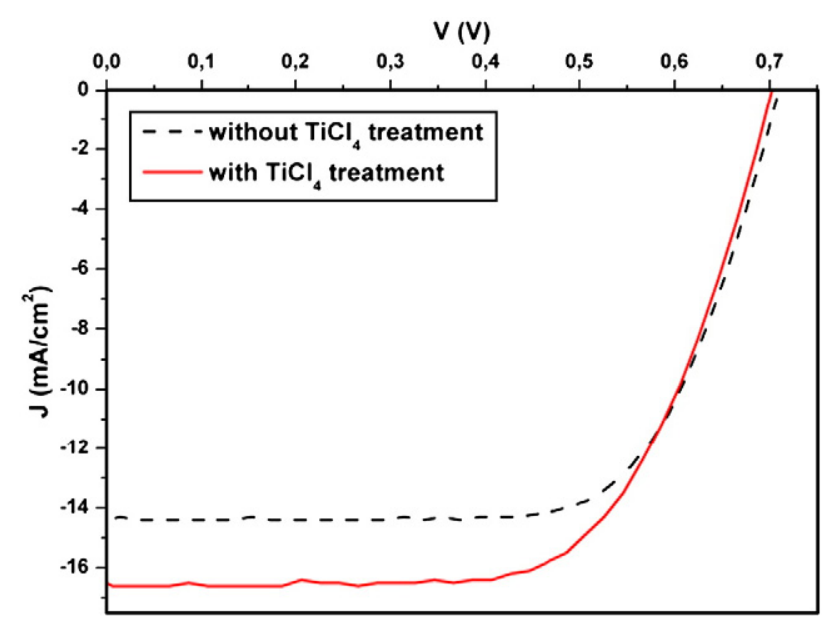

Fig. 2. J-V characteristics curves.

(a) shows the particles and sponge-like morphology of the $\mathrm{TiO}_{2}$ film before treatment. Fig. 1(b) shows the piled-needle-like shapes after $\mathrm{TiCl}_{4}$ chemical bath deposition and washing. Fig. 1(c) shows the disappearance of new shapes and improvement of particles necking by re-annealing the photo-electrode [15]. The J/V characteristics of the samples are in Fig. 2 and the cell parameters such as the short-circuit current density $\left(\mathrm{J}_{\mathrm{sc}}\right)$, open circuit voltage $\left(\mathrm{V}_{\mathrm{oc}}\right)$, fill factor $(\mathrm{FF})$ and conversion efficiency $(\eta)$ are in Table 1 . The increase in the current density and cell efficiency upon $\mathrm{TiCl}_{4}$ treatment is $14.5 \%$ and $7 \%$ respectively, while $V_{o c}$ does not change considerably. The enhancement in solar cell performance completely produces an improvement in the current density different from efficiency because of the FF decrease. We note that the enhancement of $\mathrm{TiCl}_{4}$ treatment held out during time, also after two months from the fabrication of the DSCs (Table 1).

IPCE measurements were conducted to analyze enhanced $\mathrm{J}_{\mathrm{sc}}$ in more detail (Fig. 3). A comparison of the IPCE curves revealed an upward shift of the cell with a treated $\mathrm{TiO}_{2}$ layer with respect to the cell with the untreated $\mathrm{TiO}_{2}$ layer in the wavelength range from 400 to $750 \mathrm{~nm}$.

Dark current characteristics of cells with a treated and untreated titania layer are illustrated in Fig. 4 to evaluate the recombination behavior of the devices.

\section{Discussion}

The $\mathrm{TiCl}_{4}$ treatment results in an improvement in the photocurrent, normally between $5 \%$ and $30 \%$, depending on the quality of $\mathrm{TiO}_{2}$ used to process the initial film. Typically the largest improvements come when using $\mathrm{TiO}_{2}$ films of the poorest quality [14]. Considering that $\mathrm{TiCl}_{4}$ treatment does not significantly raise the amount of the dye present or
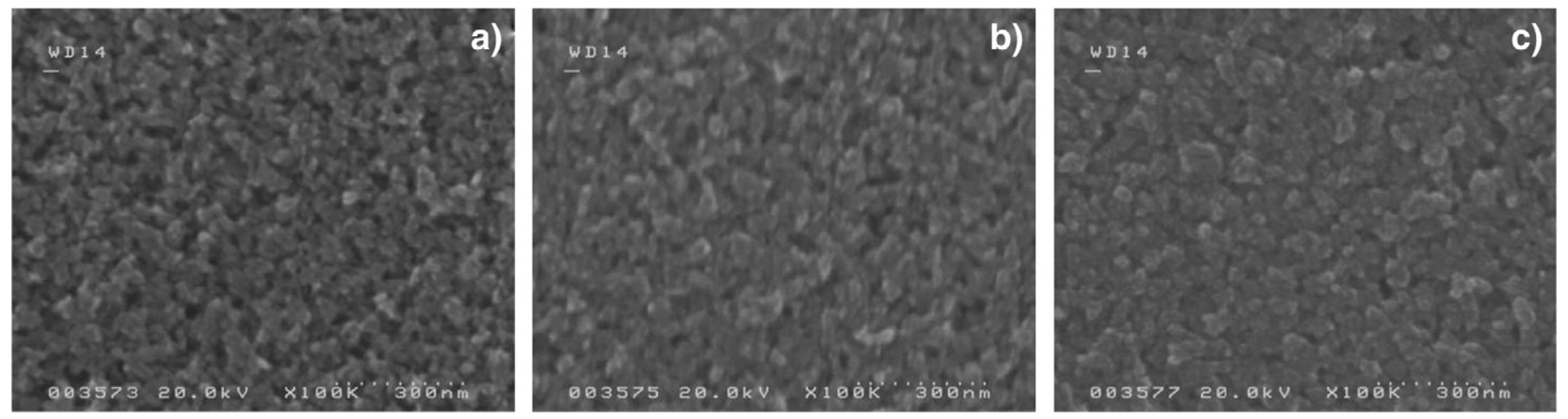

Fig. 1. SEM images of $\mathrm{TiO}_{2}$ nanoparticles films untreated (a), after $\mathrm{TiCl}_{4}$ treatment before annealing (b) and after $\mathrm{TiCl}_{4}$ treatment and annealing (c). 
Table 1

$\mathrm{J}-\mathrm{V}$ parameters of cells. Error in efficiency of each cell is less than $4 \%$.

\begin{tabular}{llllll}
\hline & $\begin{array}{l}\mathrm{J}_{\mathrm{sc}} \\
\left(\mathrm{mA} / \mathrm{cm}^{2}\right)\end{array}$ & $\begin{array}{l}\mathrm{J}_{\mathrm{sc}} \text { after two months } \\
\left(\mathrm{mA} / \mathrm{cm}^{2}\right)\end{array}$ & $\begin{array}{l}\mathrm{V}_{\mathrm{oc}} \\
(\mathrm{mV})\end{array}$ & $\begin{array}{l}\mathrm{FF} \\
(\%)\end{array}$ & $\begin{array}{l}\eta \\
(\%)\end{array}$ \\
\hline Untreated & 14.5 & 12.5 & 714 & 68.42 & 7.06 \\
$\mathrm{TiCl}_{4}$ treated & 16.6 & 14.9 & 706 & 64.62 & 7.56 \\
\hline
\end{tabular}

the light scattering, the increased photocurrent must then arise from improvements in either the charge separation or the collection efficiency.

Starting at the assumption that the electron transport in a mesoporous $\mathrm{TiO}_{2}$ electrode is assumed to proceed by diffusion in absence of a significant electrical potential gradient in the film [18], necking between $\mathrm{TiO}_{2}$ particles significantly influences the electron transport properties, characterized by the effective diffusion coefficient [19]. As has been already demonstrated, the electron diffusion coefficient of the mesoporous $\mathrm{TiO}_{2}$ electrode treated with $\mathrm{TiCl}_{4}$ (posttreatment) increases, with respect to the untreated electrode [15]. The increase in the necking between the particles (Fig. 1) will facilitate percolation of electrons from one particle to another and will reduce the recombination probability between the mediator and the semiconductor layer. Nevertheless, neither the charge collection nor the photocurrent improve as the following formula shows:

$\Phi_{C}=\frac{K_{T}}{K_{T}+{ }^{T} K_{R}}$,

where $K_{T}$ is the charge transport rate, $K_{R}$ is the charge recombination rate and $\Phi_{C}$ is the collection efficiency of the injected electrons assumable unitary.

As widely accepted, some of the effects of $\mathrm{TiCl}_{4}$ post-treatment are a decrease in the BET (Brunauer Emmett Teller) surface area and an increase in the particle diameter and mass of the treated $\mathrm{TiO}_{2}$ film [20]. We experimentally verified that $\mathrm{TiCl}_{4}$ treatment produced an increase in the $\mathrm{TiO}_{2}$ particle diameter (Fig. 1), a significant film mass (35\%) and no modification in the layer thickness profile. This is explained by a decrease in the BET surface area; it is possible that the $\mathrm{TiCl}_{4}$ removes specific surface states that serve to quench the dye excited state, improving the binding of the dye on the $\mathrm{TiO}_{2}$ film and reducing the fraction of the $\mathrm{TiO}_{2}$ film inaccessible for the dye $[13,20]$.

The $\mathrm{TiCl}_{4}$ treatment on $\mathrm{TiO}_{2}$ film produces a downward shift in the conduction band [20] and consequently results in enhancing the electron injection efficiency. This is the main cause of the upward shift in the photo-injected current (Fig. 2) and the IPCE curve (Fig. 3) of the $\mathrm{TiCl}_{4}$ treated cells with respect to the untreated cells. A decrease in Voc, caused by the downward shift of the quasi-Fermi level, is compensated

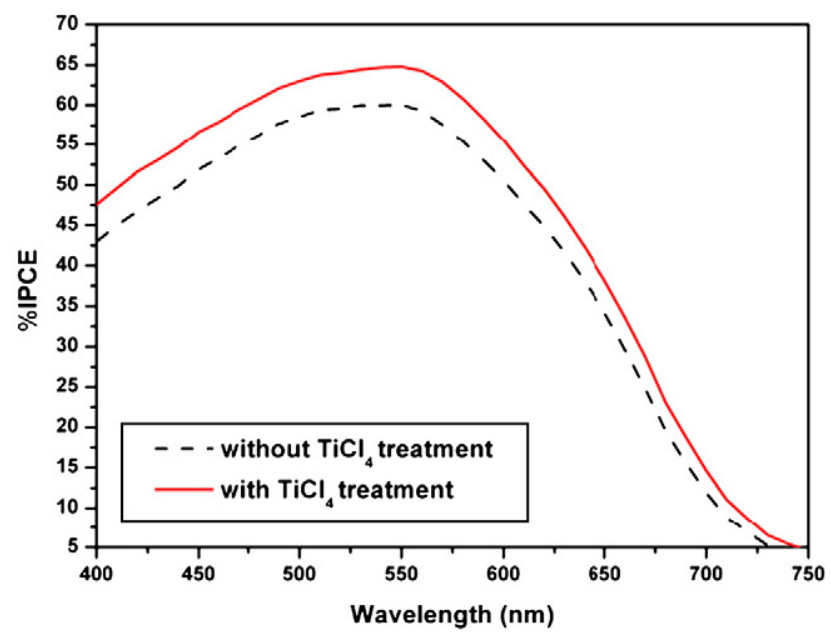

Fig. 3. IPCE of dye-sensitized solar cells without and with $\mathrm{TiCl}_{4}$ treatment.

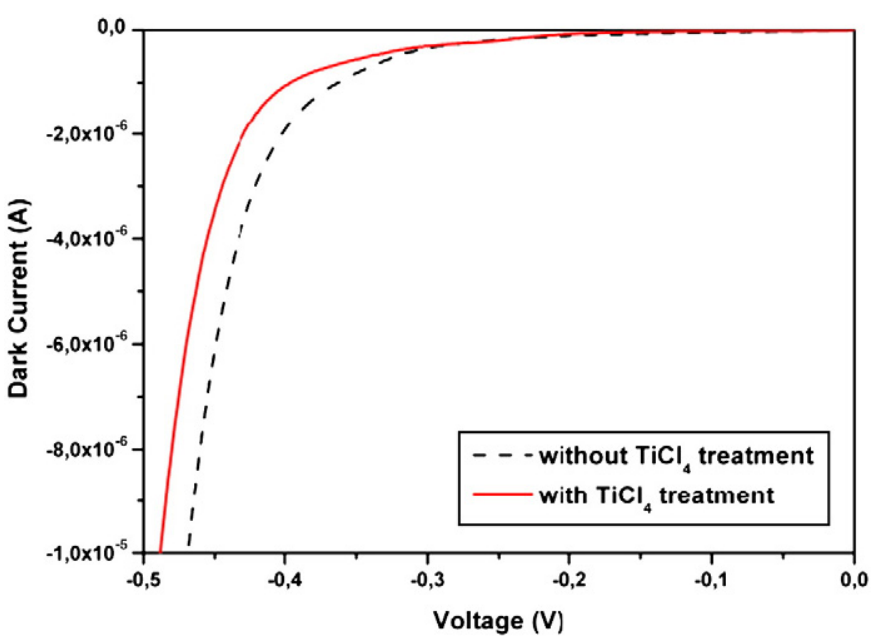

Fig. 4. Dark current-voltage characteristics curves of dye-sensitized solar cells before and after $\mathrm{TiCl}_{4}$ treatment.

through a significant reduction of the charge recombination rate due to the post- and pre-treatment, letting the Voc value under light practically unchanged (Table 1, Fig. 2).

The effective blocking layer obtained with the $\mathrm{TiCl}_{4}$ pre-treatment on the glass substrate decreases the transfer resistance (at the expense of FF) of the thin conductive oxide (TCO) and the new nanoparticles enhance the surface area to suppress the charge recombination. The $\mathrm{TiCl}_{4}$ pre-treatment enlarges the contact interface and increases the contact points between the $\mathrm{TiO}_{2}$ film and the FTO. We notice, in fact, that the removal of the $\mathrm{TiO}_{2}$ film from the conductive glass, by using solvents, is harder than in the untreated case. The $\mathrm{TiCl}_{4}$ pre-treatment also improves the electronic interconnection, so that the photoelectrons can be collected efficiently and the probability of electron recombination can be reduced [21]. Fig. 4 points out the dark current suppression for DSC with the FTO glass treated because of the tri-iodide reduction at the exposed part of TCO.

Finally, experiments with different concentrations from $10 \mathrm{mM}$ to $80 \mathrm{mM}$ and different volumes from 30 to $180 \mathrm{ml}$ of the $\mathrm{TiCl}_{4}$ solution for six photo-electrodes were also carried out. They demonstrated that 30 to $50 \mathrm{mM}$ could be considered the right concentration of the solution to obtain optimized treatment and any difference could be noticed by varying the $\mathrm{TiCl}_{4}$ bath volume used for the treatments (not shown).

This can be due to an increase in the electron trap sites on the $\mathrm{TiO}_{2}$ surface with the surface area decreased by the $\mathrm{TiCl}_{4}$ treatment [21]. In fact, concentrations higher than $50 \mathrm{mM}$ favor an increase in the nucleation of nanoparticles by reducing the film porosity and introducing a larger dark current, consequently.

\section{Conclusions}

In summary, although $\mathrm{TiCl}_{4}$ pre- and post-treatment always produces improvements on the DSC performance, the degree of improvement is variable and strongly depends on the starting $\mathrm{TiO}_{2}$ material and on precise control of the concentration of the $\mathrm{TiCl}_{4}$ aqueous solution.

The improvement introduced by pre-treatment is attributed to the enhancement of electrical contiguity at the $\mathrm{FTO} / \mathrm{TiO}_{2}$ interface and to the reduction of the charge recombination due to the exposed part of FTO at the interface between the conducting glass and the electrolyte. In fact, the dark current characteristics demonstrate that the introduction of a blocking layer, between the FTO conducting glass and the $\mathrm{TiO}_{2}$ film, by the $\mathrm{TiCl}_{4}$ treatment, suppresses the dark current. At the same time, the increase in the photocurrent is not caused by an increase in light harvesting but by an enhancement in the electron 
injection efficiency. Furthermore, the $\mathrm{TiCl}_{4}$ post-treatment usefully concurs to improve the electrical contiguity of the $\mathrm{TiO}_{2}$ film by enhancing the neck between the nanoparticles and minimizing the recombination rate between the $\mathrm{TiO}_{2}$ film and the mediator. As a consequence of complete $\mathrm{TiCl}_{4}$ treatment, the samples exhibit an improvement of the photocurrent density without any sensible $\mathrm{V}_{\mathrm{oc}}$ variation.

\section{Acknowledgements}

We gratefully thank Dr. Angelo Lembo from Dyesol Italia for his helpful assistance in the $\mathrm{TiCl}_{4}$ chemical preparation, Alessandro Lanuti at CHOSE, University of Rome "Tor Vergata", for screen-printing the counter-electrodes and Valeria Guglielmotti at the Department of Chemical Science and Technology, University of Rome "Tor Vergata", for her aid with the SEM. We also acknowledge the financial support of this work by Regione Lazio "Polo Solare Organico".

\section{References}

[1] B.C. O'Regan, M. Graetzel, Nature. 353 (1991) 737.

2] A. Hagfeldt, M. Graetzel, Chem. Rev. 95 (1995) 49

[3] X. Chen, S.S. Mao, Chem. Rev. 107 (2007) 2891.

[4] L. Vesce, G. Perillo, R. Riccitelli, G. Soscia, T. M. Brown, A. Di Carlo, A. Reale, manuscript in preparation.
[5] M. Wei, Y. Konishi, H. Zhou, M. Yanagida, H. Sugihara, H. Arakawa, J. Mater. Chem. 16 (2006) 1287.

[6] T. Ma, T. Kida, M. Akiyama, K. Inoue, S. Tsunematsu, K. Yao, H. Noma, E. Abe, Electrochem. Comm. 5 (2003) 369.

[7] P. Wang, S.M. Zakeeruddin, P. Comte, R. Charvet, R. Humphry-Baker, M. Graetzel, J. Phys. Chem., B. 107 (2003) 14336.

[8] Z.-S. Wang, H. Kawauchi, T. Kashima, H. Arakawa, Coord. Chem. Rev. 248 (2004) 1381.

[9] S. Ito, T. Murakami, P. Comte, P. Liska, C. Graetzel, M. Nazeeruddin, M. Graetzel, Thin Solid Films. 516/14 (2008) 4613.

[10] C. Hägglund, M. Zäch, B. Kasemo, App. Phys. Lett. 92 (2008) 013113.

[11] M. Nazeeruddin, A. Kay, I. Rodicio, R. Humphry, E. Muller, P. Liska, N. Vlachopoulos, M. Graetzel, J. Am. Chem. Soc. 115 (1993) 6382.

[12] S. Ito, P. Liska, P. Comte, R. Charvet, P. Péchy, U. Bach, L. Schmidt-Mende, S.M. Zakeeruddin, A. Kay, M.K. Nazeeruddin, M. Graetzel, Chem. Comm. (2005) 4351.

[13] S. Ito, K. Ishikawa, C.-J. Wen, S. Yoshida, T. Watanabe, Bull. Chem. Soc. Jpn. 73 (2000) 2609.

[14] B.C. O'Regan, J.R. Durrant, P.M. Sommeling, N.J. Bakker, J. Phys. Chem. C. 111 (2007) 14001.

[15] S. Kambe, S. Nakade, Y.Wada, T. Kitamura, S. Yanagida,J. Mater. Chem. 12 (2002) 723.

[16] C.J. Barbé, F. Arendse, P. Comte, M. Jirousek, F. Lenzmann, V. Shklover, M. Graetzel, J. Am. Ceram. Soc. 80 (12) (1997) 3157.

[17] G. Mincuzzi, L. Vesce, A. Reale, A. Di Carlo, T.M. Brown, Appl. Phys. Lett. 95 (2009) 103312.

[18] S. Fan, C. Li, G. Yang, L. Zhang, Rare Metals. 25 (2006) 163.

[19] M.J. Cass, F.L. Qiu, A.B. Walker, A.C. Fisher, L.M. Peter, J. Phys. Chem. B. 107 (2003) 113.

[20] P.M. Sommeling, B.C. O'Regan, R.R. Haswell, H.J.P. Smit, N.J. Bakker, J.J.T. Smits, J.M. Kroon, J.A.M. van Roosmalen, J. Phys. Chem. B. 110 (2006) 19191.

[21] W. Xu, S. Dai, L. Hu, C. Zhang, S. Xiao, X. Luo, W. Jing, K. Wang, Plasma Science and Technology. 9 (5) (2007) 556. 